\title{
The Effect of Job Satisfaction to Organizational Citizenship Behavior (OCB) Mediated by Organizational Commitment
}

\author{
Tomy Fitrio $^{* a}$, Roky Apriansyah ${ }^{\text {b }}$, Sabrina Utami ${ }^{c}$, Hasanah Yaspita ${ }^{d}$ \\ *a,b,c,d Economics College of Indragiri (STIE-I) Rengat Indonesia
}

\begin{abstract}
This research aimed to find out the effect of job satisfaction to organizational citizenship behavior, organizational commitment to organizational citizenship behavior, and job satisfaction to organizational citizenship behavior mediated by organizational commitment at Economics College of Indragiri Rengat. The number of the sample in this research is 34, filled by the lectures of Economics College of Indragiri Rengat. This research used Saturated Sampling methods, where all population as the sample of this research. To collect all the data, this research used Closed Questionnaires techniques. This research used Likert Scale as data measurement techniques. This research used Structural Equation Modeling (SEM) as data analysis techniques operated by Smart PLS 3.0 application. This research shows that: (1) job satisfaction has apositive and significant effect to organizational citizenship behavior (OCB), (2) organizational commitment has a positive and significant effect to organizational citizenship behavior (OCB), (3) job satisfaction has apositive and significant effect to organizational citizenship behavior (OCB), (4) organizational commitment mediated the effect between job satisfaction to organizational citizenship behavior (OCB) positively and significantly.
\end{abstract}

Keywords: Job Satisfaction, Organizational Commitment, Organizational Citizenship Behavior

\section{Introduction \\ Background}

The term Organizational Citizenship Behavior (OCB) is expressed by Organ and Bateman (1983). Robbin (2008) Organizational Citizenship Behavior (OCB) emphasizes cooperative behaviors and mutual assistance that are outside the formal requirements. Organizational Citizenship Behavior (OCB) is extra individual behavior, which is not directly or explicitly recognizable in a system formal work, and in aggregate able to improve the effectiveness of organizational functions (Turnipseed, 2005). Julian and Nurasiah (2017) in their research found that the Application of Organizational Citizenship Behavior (OCB) greatly helped a Lecturer in carrying out Tri Dharma College such as developing teaching methods, conduct research in accordance with interests and scientific fields, and contribute to community service programs. And by that, the writer is interested to see OCB's behavior at Economics College of Indragiri Rengat.

\section{Review of Literature Study}

\section{Job satisfaction affects Organizational Citizenship Behavior}

Hasibuan (2005) job satisfaction is "an emotional attitude that is pleasant and loves his work". Hariandja (2001) there are factors that influence job satisfaction: (a) Salary, (b) Work itself, (c) Colleagues, (d) Tops, Promotions, and (e) Work environment. According to Fattah (2017) job satisfaction is a state of positive emotion that results from evaluating one's work experience. Further said that the dimensions of job satisfaction include: the job, salary, opportunities for promotion, supervision and co-workers. Robbins (1996) explains that the impact of job satisfaction includes: (1) job satisfaction and job performance, (2) job satisfaction and OCB (Organizational Citizenship Behavior), (3) job satisfaction and customer satisfaction (4) job satisfaction and absenteeism , (5) job satisfaction and turnover, (6) job satisfaction and workplace deviance, (7) managers often "don't get it". 
Dharma (2005) organizations that are successful in achieving their goals, one of them is because the organization is able to meet the job satisfaction of its employees. Handoko (1987) job satisfaction is an assessment or reflection of workers' feelings for their work. According to Luthans (1995) there are factors that influence job satisfaction: (1) payments, such as salaries and wages, (2) work itself, (3) Promotion of jobs, (4) Supervision (supervision), (5) Colleagues .

Schwab (1970) there are six factors that cause job satisfaction or often also equated with pleasant experiences for employees: (1) achievement, (2) appreciation for achievement, (3) work itself, (4) responsibility, (5 ) promotion, and (6) opportunities to develop. Savery (1987) states that low job satisfaction causes productivity is also low. Yousef (2002) illustrates job satisfaction as a pleasant or positive emotional state that results from an assessment of one's work or work experience. Noermijati (2013) job satisfaction is a result of employee perceptions of the extent to which their work can provide such emotional states.

Handoko (2000) argues that job satisfaction is a pleasant or unpleasant emotional state of the employees in looking at their work. Tangkilisan (2005) job satisfaction is the level of pleasure someone feels for his role or work in the organization. Job satisfaction is the level of satisfaction of individuals that they are rewarded in kind from various aspects of the work situation of the organization they work for. So job satisfaction concerns the psychological individual in the organization, which is caused by the circumstances that he feels from his environment.

Ivancevich (2006) job satisfaction is a person's attitude towards their work. This results from their perceptions of their work and the degree of conformity between individuals and organizations. Ivancevich (2006) A number of factors are associated with job satisfaction, namely: (1) the reward is the amount of payment received and the degree of conformity between the payment and the work done, (2) the work itself is the extent to which the work is considered attractive and giving responsibility, (3) promotion opportunities, namely the availability of opportunities for advancement, (4) supervision, namely technical competencies and interpersonal skills of direct superiors, (5) co-workers namely the extent to which colleagues are friendly, competent and provide support, (6) Job conditions are the extent to which the physical work environment provides comfort and supports productivity, (7) job security, namely the belief that one's position is relatively safe and there is an opportunity to continue working in the organization.

Madura (2007) the main characteristics that influence job satisfaction are money, security, work schedules and involvement in the workplace.

H1: Job satisfaction affects Organizational Citizenship Behavior (OCB)

\section{Job satisfaction affects organizational commitment}

Organizational commitment is an attitude where the individual identifies himself with the goals and expectations of the organization where he works and tries to maintain membership in the organization to realize the goals of the organization, Porter and Minner (1988)

indicator of organizational commitment according to Porter and Mowday in Busro Muhammad (2018): (a) Affective commitment, namely commitment that proposes to the emotional relationship of members to the organization, (b) Continuous commitment, which proposes the desire of employees to stay in the organization, ( c) Normative commitment, which refers to the feelings of employees where they are required to remain in their organization because of pressure from others.

Balfour and Wechsler (1996) some of the outcomes that arise from organizational commitment: (1) the desire to survive (Desire to Remain) is the outcome of three forms (dimensions) of organizational commitment. Employees wishing to stay in the organization are because they have a high level of identification (internalization) of the organization's mission, goals and achievements and have satisfaction in the process of reciprocal relationships with the organization and have strong social attachments to other members of the organization, (2) intense turnover reflects the desire individuals to look for alternative jobs and leave the organization. Thus someone's desire to survive in the organization reduces his intention to find alternative jobs outside the organization, (3) Extra-Role behavior (Extrarole Behavior) that is someone who has strong social links to other members in the organization is more likely to make more effort to help their relations and organization.

Meyer and Allen (1993) there are three components of organizational commitment: (1) affective commitment is an emotional approach of individuals in their involvement with the organization, so that 
individuals will feel associated with the organization, affective commitment is related to employees' emotional attachment, identification employees in the organization, and employee involvement in the organization. Thus, employees who have strong affective commitment will continue to work in the organization because they really want (want to) do that. In other words, one's emotional involvement in the organization in the form of feelings of love for the organization, (2) continuance commitment is the desire that individuals have to survive in the organization, so that individuals feel the need to be associated with the organization. Continuous commitment relates to one's perception of costs and risks by leaving the current organization. This means that there are two aspects to continuous commitment that involve personal sacrifice when leaving the organization and the absence of alternatives available to the person. and (3) normative commitment (normative commitment) is a feeling obligatory of individuals to survive in the organization. A moral dimension based on feelings of obligation and responsibility for the organization that employs it. In other words, normative commitment is related to the feeling of being obliged to continue working in the organization. This means that employees who have high normative commitments feel that they are obliged (ought to) to stay within the organization.

O'Reilley and Chatman (1986) organizational commitment is the bond of individual psychology to the organization including job involvement (job involvement), loyalty, and confidence in organizational values. Organizational commitment from this view is characterized by members' acceptance of organizational goals and their willingness to increase business while working (Miller and Lee, 2001).

Cohen (2007) explained that commitment is a force that binds an individual to take an action towards one or several goals. Arnold (2005) in Cohen (2007) namely the relative strength of individual identification and involvement in the organization.

Miller (2003) in Coben (2007) asserted that organizational commitment is a condition in the member who then identifies it with the member who then identifies with the characteristics and goals of the organization and maintains its membership in the organization. Morrow (1993) in Cohen (2007) describing organizational commitment is characterized by attitudes and behavior. Miller in Cohen (2007) organizational commitment describes attitudes as evaluative statements or judgments, both supporting and not supporting, on certain phenomena. Organizational commitment is an attitude that reflects feelings, such as attachment, identification and loyalty to the organization as an object of commitment.

Morrow (1993) in Weibo, Kaur, Jun (2010) explains that individuals who commit to take special actions or behaviors are based on moral beliefs rather than just thinking about personal gain. Reichers in Cohen (2007), it is explained that commitment as a visible behavior is shown when organizational members have commitment to their group within an organization.

Miller and Lee (2001) organizational commitment is a situation in which members of an organization are bound to their activities and beliefs, while their function is to maintain their activities and involvement in the organization. Miner (1988) conceptually, commitment can be characterized at least by three things, namely (1) strong belief in the acceptance of organizational goals and values, (2) the desire to expand efforts in behavior in organizations, and (3) strong desire to maintain membership in the organization.

Mathis and Jackson (2001) organizational commitment is a level of trust and acceptance of labor towards organizational goals and has a desire to remain in the organization. Suryaman (2016) when employees do not have commitment to the organization, they will work indifferently and will not be able to produce high performance which in the end they will leave the organization, either because of their own awareness or dismissed by the company.

Steers in Yuwalliatin (2006) defines organizational commitment as a sense of identification, involvement and loyalty expressed by an employee towards his organization. The sense of identification, involvement and loyalty shown by employees towards their superiors cannot be made up or wrapped in words as if, but it will be very self-evident, who among loyal employees and non-loyal employees is seen from the seriousness of work and performance resulting from.

H2: Job satisfaction affects organizational commitment

Organizational commitment affects Organizational Citizenship Behavior (OCB) 
The term Organizational Citizenship Behavior (OCB) was first proposed by the Organ which suggested five primary dimensions of OCB in the book Budiharjo Andreas (2011: 140-141): (a) Altruism that is the behavior of helping other employees without any coercion to tasks that are closely related organizational operations, (b) Civic Virtue, demonstrates voluntary participation and support for organizational functions both professionally and naturally. (c) Conscinetiousness, which contains the performance of the role prerequisites that exceed the minimum standards, (d) Courtesy, is behavior alleviates the problems associated with the work faced by others. (e) Sportmanship, containing abstinence makes a damaging issue even though it is annoying.

Katz (1964) states that Organizational Citizenship Behavior (OCB) is innovative and spontaneous behavior. Johns (1996) suggests that Organizational Citizenship Behavior (OCB) is voluntary behavior (extra role behavior) that is not in the job description, spontaneous behavior of employees without someone's advice or orders that are helpful. These spontaneous and voluntary behaviors are often not assessed by management. In other words, the behavior is not rewarded. Even that, the perpetrators obeyed the principle of behavior. Riso \& Hudson (2000) the concept of OCB can be explained by using the Enneagram personality concept. This behavior strongly supports the organizational climate in achieving its goals. It can be imagined if most members of the organization have high OCB employees, there will be positive implications for the company's performance.

Podsakoff (2000) suggested seven dimensions of Organizational Citizenship Behavior (OCB), namely: (1) Helping Behavior, namely willingness to help others, (2) sportsmanship (sportsmanship behavior) is the condition of still working in an organization without complaining though unpleasant organizational conditions, (3) organizational compliance is a willingness to accept company rules and procedures, (4) Organizational Loyalty (Loyal behavior) is an effort to promote the company to other parties, protect and defend it from external threats, and remain survive being a member of the organization whatever the risks, (5) civic virtue / organizational participation is an involvement in organizational activities and concern for the survival of the organization, (6) Self development (self development) is an individual effort to increase knowledge, skills and abilities without being asked, (7) individual initiative is an individual voluntary effort to improve the pattern of working creatively for the sake of improving organizational performance.

William and Anderson (1991) Organizational Citizenship Behavior (OCB) is discretionary and not rewarded directly. According to William and Anderson (1991) identified two broad categories of Organizational Citizenship Behavior (OCB), namely: (1) OCBO (Organizational Citizenship Behavior-Organization), which is behavior that benefits the organization in general, for example prior notification when it cannot come to work and, (2) OCBI Organizational Citizenship Behavior-individuals, ie behavior that directly benefits certain individuals and indirectly through these individuals can contribute more to the company, for example, helping an employee carry out certain tasks.

Organ, Smith and Near (1983) Organizational Citizenship Behavior (OCB) is a relatively new concept in industrial / organizational psychology. Hannam, R and Jimmieson, N (2004) Organizational Citizenship Behavior (OCB) is behavior in the workplace that exceeds work requirements or goes beyond the call of duty. Deshpande (2002) Organizational Citizenship Behavior (OCB) is a behavior that is formally determined but is needed by the organization.

McShane and Von Glinow (2010) mention Organizational Citizenship Behavior (OCB), which are various forms of cooperation and helpfulness to others that support the organization's social and phychological context along with task performance. Ogan (1988) Organizational Citizenship Behavior (OCB) is an individual behavior that is abstract, not directly recognized by the formal reward system, and that is aggregated prompted by the effective functioning of the organization. By means of an organization, we mean that the employment contract is a contract with the organization.

H3: Organizational commitment affects Organizational Citizenship Behavior (OCB)

Organizational commitment mediates the effect of job satisfaction on Organizational Citizenship Behavior (OCB) behavior 
Luthans (2006) organizational commitment is a strong desire to remain as a member of a particular organization, the desire to strive in accordance with the wishes of the organization and certain beliefs as well as acceptance of values and goals of the organization.

Cut Zurnali (2010) defines the dimensions of organizational commitment as follows: (1) affective commitment is a feeling of love for the organization that raises the willingness to stay and foster social relationships and respect the value of relationships with organizations because they have become members of the organization, (2) continuance commitment is a heavy feeling to leave the organization because of the need to survive with consideration of costs when leaving the organization and the respect regarding participation in the organization (3) normative commitment is a feeling that requires staying in the organization based on consideration of employee norms, values and beliefs.

Robbins and Judge (2015) there are three organizational commitments, namely: (1) affective commitment, namely emotional feelings for the organization and confidence in its values, (2) continuance commitment, namely economic value that is felt from survival in an organization when compared to leaving the organization. An employee may commit to an employer because he is highly paid and feels that resignation from the company will destroy his family. (3) normative commitment, namely the obligation to stay in the organization for moral or ethical reasons. Someone will survive with an employer because he feels he is leaving someone in a difficult situation when he leaves.

Steers (1988) grouping organizational commitment into three factors, namely: (1) identification with the organization that is acceptance of organizational goals, where this acceptance is the basis of organizational commitment. Employee identification appears through the attitude of agreeing to the wisdom of the organization, the similarity of personal values and organizational values, pride is part of the organization, (2) involvement, namely the willingness to strive for the organization. Engagement according to the role and responsibility of work in the organization. Employees who have a high commitment will receive almost all tasks and job responsibilities given to him, (3) loyalty, namely the strong desire to maintain membership in the organization. Loyalty to the organization is an evaluation of commitment, as well as the emotional ties and attachments between the organization and employees. Employees with high commitment feel the presence of loyalty and belonging to the organization.

Miroshnik (2013) propose three types of commitments: (1) Sacrifice and investment support continuance (sacrifice and investment support for sustainability), (2) renunciation and communion support cohesion (rejection and support for integrated integration), (3) mortification and surrender support control (heartache and support for self-release control).

Mowday, et. al (Stroh \& Gregory B. Northcraft, 2002) suggest a number of factors that can increase the level of commitment, namely: (1) personal factors are the tendency of employees to develop stable attachments to organizations, (2) organizational factors are organizational characteristics such as concern for employee interests or employee ownership, (3) the main non organizational factor that increases commitment is the availability of alternatives after the initial choice to join the organization. Commitment will occur if employees (a) have sufficient external justification for their initial choice and (b) the choice view as relatively irrevocable; that is, they believe that they don't have the next opportunity that will guarantee they change their minds.

Kochan and Dyer (Armstrong, 2006), the factors that influence the level of shared commitment called corporate commitment are as follows: (1) Strategic level: (a) business strategy that supports, (b) commitment to management values, (c ) effective opinions on resources in making strategies; (2) functional level (human resource policy): (a) staffing based on work stabilization, (b) investment in training and development, (c) contingent compensation that strengthens cooperation, participation and contribution; (3) level of work: (a) choices based on high standards, (b) extensive task design and teamwork, (c) employee involvement in problem solving, (d) climate of cooperation and trust.

Steers (1977) organizational commitment includes: (1) personal characteristics consisting of age, years of service, level of education, gender, ethnicity and personality correlate with organizational commitment, (2) characteristics related to position or role having donations that meaningful to organizational commitment. These characteristics include job challenges, role conflict, and role ambiguity, (3) work experience contributes most to the organization. This work experience includes the reliability of the organization, 
feelings of importance, realization of expectations, positive coworkers' attitudes toward the organization, perceptions of salaries and norms related to hard work.

Related to organizational commitment dimensions and indicators stated by Buchanan that commitment consists of three commitments, namely: (a) identification, namely the adoption of goals and values of a person in the organization, (b) involvement, namely involvement in the organization, (c) loyalty is the attachment of one's feelings to the organization .

H4: Organizational commitment mediates the effect of job satisfaction on Organizational Citizenship Behavior (OCB)

\section{Previous Research}

Previous research on job satisfaction, organizational commitment and OCB can be seen in table 1 .

Table 1: Previous Research on job satisfaction, organizational commitment and OCB

\begin{tabular}{|c|c|c|c|}
\hline No & Author (Year) & Variable & Results \\
\hline 1. & Triwibowo et.al (2016) & $\begin{array}{l}\text { Job Satisfaction }(\mathrm{JS}) \\
\text { Organization Commitment } \\
\text { (OC) } \\
\text { OCB }\end{array}$ & $\begin{array}{l}\text { JS-OC significant } \\
\text { JS-OCB significant } \\
\text { OC-OCB Significant }\end{array}$ \\
\hline 2. & Prasetio et.al (2015) & $\begin{array}{l}\text { Job Satusfaction (JS) } \\
\text { Organization Commitment } \\
\text { (OC) } \\
\text { OCB }\end{array}$ & $\begin{array}{l}\text { JS-OC significant } \\
\text { JS-OCB significant } \\
\text { OC-OCB Significant }\end{array}$ \\
\hline 3. & Zeinabadi (2010) & $\begin{array}{l}\text { Job Satisfaction (JS) } \\
\text { Organization Commitment } \\
\text { (OC) } \\
\text { OCB }\end{array}$ & $\begin{array}{l}\text { JS-OC significant } \\
\text { JS-OCB significant } \\
\text { OC-OCB Significant }\end{array}$ \\
\hline 4. & Sukmawati et.al (2013) & $\begin{array}{l}\text { Job Satisfaction (JS) } \\
\text { Organization Commitment } \\
\text { (OC) } \\
\text { OCB }\end{array}$ & $\begin{array}{l}\text { JS-OC not significant } \\
\text { JS-OCB significant } \\
\text { OC-OCB Significant }\end{array}$ \\
\hline 5. & Sesen et.al (2012) & $\begin{array}{l}\text { Job Satisfaction (JS) } \\
\text { Organization Commitment } \\
\text { (OC) } \\
\text { OCB }\end{array}$ & $\begin{array}{l}\text { JS-OC significant } \\
\text { JS-OCB significant } \\
\text { OC-OCB Significant }\end{array}$ \\
\hline 6. & Qomar (2012) & $\begin{array}{l}\text { Job Satisfaction }(\mathrm{JS}) \\
\text { Organization Commitment } \\
\text { (OC) } \\
\text { OCB }\end{array}$ & $\begin{array}{l}\text { JS-OC significant } \\
\text { JS-OCB significant } \\
\text { OC-OCB Significant }\end{array}$ \\
\hline 7. & Schappe (2010) & $\begin{array}{l}\text { Job Satisfaction (JS) } \\
\text { Organization Commitment } \\
\text { (OC) } \\
\text { OCB }\end{array}$ & $\begin{array}{l}\text { JS-OC significant } \\
\text { JS-OCB significant } \\
\text { OC-OCB Significant }\end{array}$ \\
\hline 8. & Shafazawana et.al 2015 & $\begin{array}{l}\text { Job Satisfaction }(\mathrm{JS}) \\
\text { Organization Commitment } \\
\text { (OC) } \\
\text { OCB }\end{array}$ & $\begin{array}{l}\text { JS-OC significant } \\
\text { JS-OCB significant } \\
\text { OC-OCB Significant }\end{array}$ \\
\hline 9. & Chhabra et.al (2014) & $\begin{array}{l}\text { Job Satisfaction }(\mathrm{JS}) \\
\text { Organization Commitment } \\
\text { (OC) } \\
\text { OCB }\end{array}$ & $\begin{array}{l}\text { JS-OC significant } \\
\text { JS-OCB significant } \\
\text { OC-OCB Significant }\end{array}$ \\
\hline 10. & Shurbagi et.al (2014) & $\begin{array}{l}\text { Job Satisfaction }(\mathrm{JS}) \\
\text { Organization Commitment } \\
\text { (OC) } \\
\text { OCB }\end{array}$ & $\begin{array}{l}\text { JS-OC significant } \\
\text { JS-OCB not significant } \\
\text { OC-OCB not significant }\end{array}$ \\
\hline
\end{tabular}




\section{Formulation of the problem}

The research questions are:

- $\quad$ Does organizational satisfaction affect organizational commitment?

- $\quad$ Does job satisfaction affect organizational citizenship behavior?

- Does organizational commitment influence organizational citizenship behavior?

- Does the organizational commitment mediate the influence between job satisfaction on organizational citizenship behavior?

\section{Conceptual Framework}

The thinking framework of this study can be seen from picture 1 .

$\mathrm{H} 1$

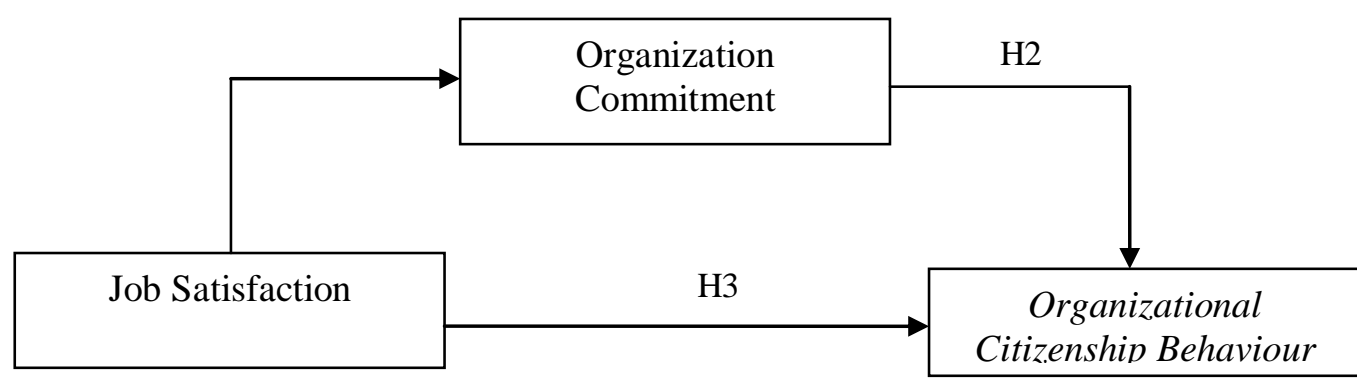

Picture 1

Conceptual Framework

\section{Methodology / Material}

This study is quantitative research. According to Sugiyono in Siyoto's book (2015: 37) quantitative research methods can be interpreted as research methods based on the philosophy of positivism, used to examine certain populations and samples. This study uses saturated sampling techniques. And this requires research instruments to collect data. After that the data is processed with a statistical program or quantitative form which aims to test the hypothesis. The population of this study were 34 lecturers at Economics College of Indragiri Rengat. The analysis technique in this study used SEM (Structural Equation Modeling) analysis which was operated through the SmartPLS 3.0 Application.

\section{Results and Discussion}

\section{Validity test}

The following are the results of the validity test obtained 


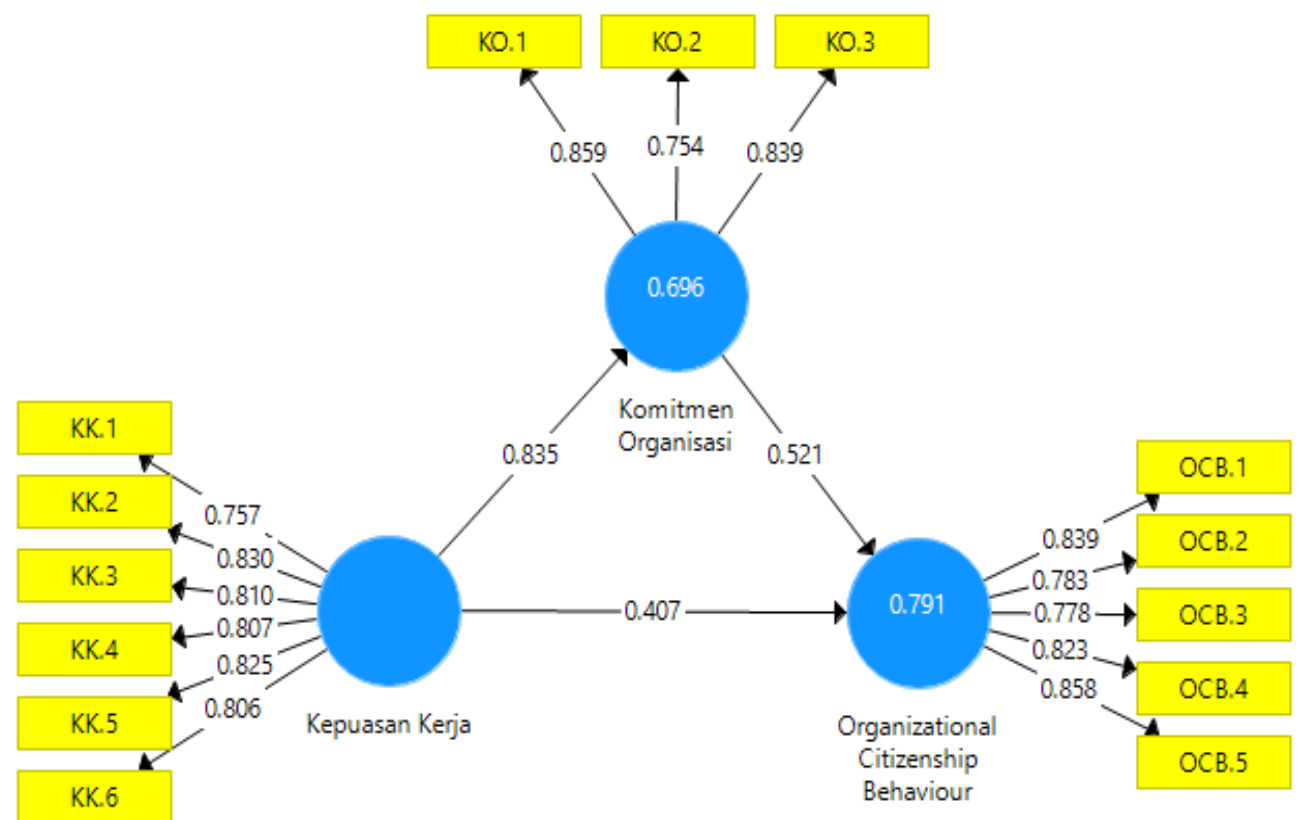

Picture 2

Validity Test

The validity of the indicator is seen from the loading factor value (LF) based on instructions. In accordance with the general rule (rule of thumb), the LF value of the indicator 70.7 is said to be valid. However, in developing a new model or indicator, the LF value between $0.5-0.6$ is still acceptable (Yamin and Kurniawan, 2011: 202). Whereas Wijaya and Mustafa (2012: 124) explain that critical indigo LF varies in criteria, but some experts suggest a minimum of 0.4. Based on the results of the print out command Calculate PLS Algorithm in picture 2. stated the value of LF $\geq 0.7$ so that all indicators on the model are said to be fit.

\section{Reliability Test}

\section{Table 1: Reliability Test}

\begin{tabular}{|l|l|l|l|l|l|l|}
\hline Variable & $\begin{array}{l}\text { Number of } \\
\text { Questions }\end{array}$ & $\begin{array}{l}\text { Cronbach's } \\
\text { Alpha } \\
\text { Value }\end{array}$ & $\begin{array}{l}\text { rho_A } \\
\text { Value }\end{array}$ & $\begin{array}{l}\text { Composite } \\
\text { Reliability } \\
\text { Value }\end{array}$ & $\begin{array}{l}\text { Minimal } \\
\text { Grade }\end{array}$ & Explanation \\
\hline $\begin{array}{l}\text { Job } \\
\text { Satisfaction }\end{array}$ & 6 & 0,892 & 0,899 & 0,918 & 0,7 & Reliable \\
\hline $\begin{array}{l}\text { Organization } \\
\text { Commitment }\end{array}$ & 3 & 0,752 & 0,758 & 0,859 & 0,7 & Reliable \\
\hline OCB & 5 & 0,875 & 0,878 & 0,909 & 0,7 & Reliable \\
\hline
\end{tabular}

Source: Processed PLS Data

The evaluation of the value of construct reliability is measured by the values of Cronbach's Alpha and Composite Reliability. The Cronbach's Alpha value for all constructs must be $\geq 0.7$. In table 1 . the value of Cronbach's Alpha all constructs is greater than 0.7, so it can be concluded that the indicators are consistent in measuring the construct.

\section{Hypothesis Test}




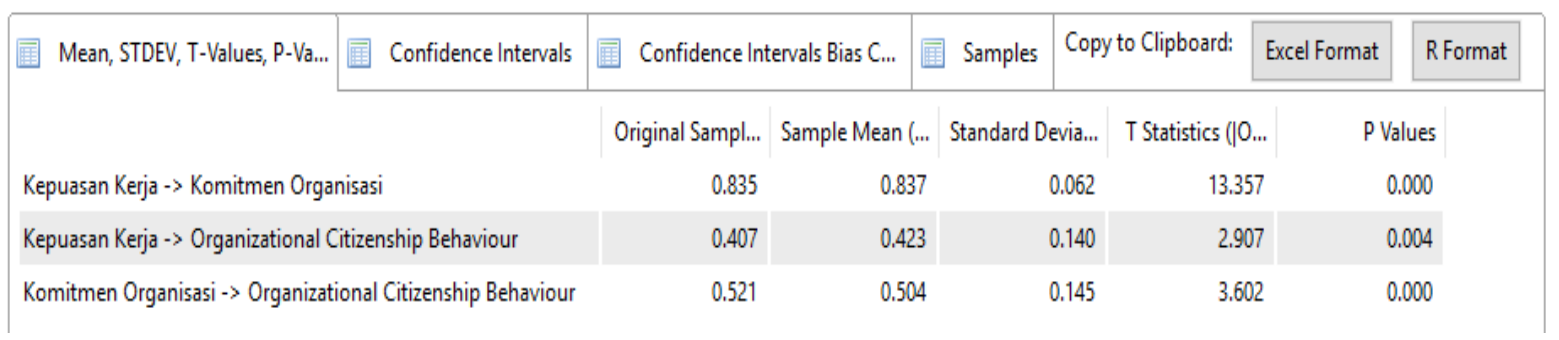

\section{Picture 3}

\section{Hypotesis Test}

At this stage the evaluation of the structural model will be analyzed by looking at the significance of the relationship between the constructs indicated by the statistical t value by looking at the output of options Calculate PLS Bootstrapping to see the TStatistic value. Where the indicator has a TStatistic value of 96 1.96 (Some are rounded to 2) said to be valid. The indicator can also be said to be valid if it has P Value $\leq$ 0.05 . As shown in picture 3 above.

\section{H1. Effect of Job Satisfaction on Organizational Commitments}

With structural equations it shows that the variable job satisfaction with organizational commitment with the value of $t$-Count $>\mathrm{t}$-Table is $13,357>1,693$. It can be concluded that job satisfaction has a positive and significant effect on organizational commitment with the results of hypothesis testing accepting $\mathrm{H} 1$ and rejecting $\mathrm{HO}$.

\section{H2. Effect of Organizational Commitment on Organizational Citizenship Behavior}

This second hypothesis from the structural equation shows that the variable organizational commitment to the Organizational Citizenship Behavior with $\mathrm{t}$-count value is 3.602> t-Table 1.693. It can be concluded that organizational commitment has a positive and significant effect on Organizational Citizenship Behavior with the results of hypothesis testing receiving $\mathrm{H} 2$ and rejecting $\mathrm{HO}$.

\section{H3. Effect of Job Satisfaction on Organizational Citizenship Behavior}

This third hypothesis from the structural equation shows that the job satisfaction variable towards the Organizational Citizenship Behavior with the value of $t$-count $>t$-table is $2.907>1.693$. It can be concluded that job satisfaction has a positive and significant effect on Organizational Citizenship Behavior with the results of hypothesis testing receiving $\mathrm{H} 3$ and rejecting $\mathrm{HO}$.

\section{H4. Effect of Job Satisfaction on Organizational Citizenship Behavior Mediated by Organizational Commitment}

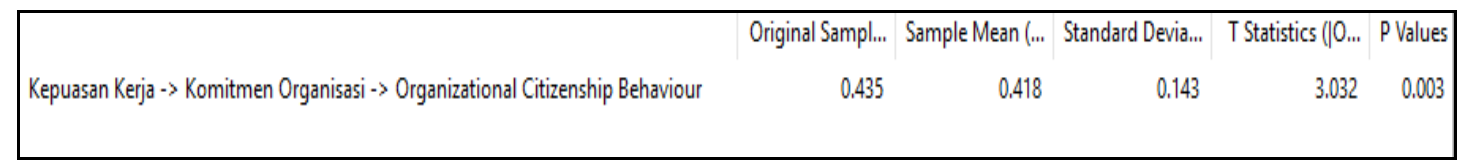

\section{Table 2}

The fourth hypothesis test is measuring the influence between variables of job satisfaction on Organizational Citizenship Behavior mediated by organizational commitment. The result is that it has a significant effect, it can be seen by comparing the value of 3.032 greater than the t-table value of 1.688 . Then it can be concluded that the results of this study organizational commitment mediate the effect of job satisfaction on Organizational Citizenship Behavior positively and significantly, meaning that testing the four accepts $\mathrm{H}_{4}$ and rejects $\mathrm{H}_{0}$.

\section{Discussion}


Job satisfaction has a positive and significant effect on organizational commitment. The results of this study are supported by previous studies conducted by Wahy Triwibowo et al. (2016), Arif Partono Prasetio et al. (2015) and Hasanreza Zeinabadi (2010) who concluded that job satisfaction affects organizational commitment. It can be concluded that the higher employee job satisfaction will directly increase the organizational commitment of the employee.

Organizational commitment has a positive and significant effect on Organizational Citizenship Behavior. The results of this study are supported by previous research conducted by Sukmawati et al. (2013), Harun Sesen et al. (2012), Nida Qomar (2012). Behavior.

Job satisfaction has a positive and significant effect on Organizational Citizenship Behavior. The results of this study are supported by previous research conducted by Stephen P Schappe (2010), Shafazawana et. al (2015), Bindu Chhabra (2014) which states that job satisfaction affects Organizational Citizenship Behavior. It can be concluded that the higher the job satisfaction felt by employees, the Organizational Citizenship Behavior will also increase.

Organizational commitment mediates the influence of job satisfaction on Organizational Citizenship Behavior positively and significantly. The results of this study are supported by previous research conducted by Wahyu Triwibowo et al. (2016), Arif Partono Prasetio et al. (2015) and Hasanreza Zeinabadi (2010), Sukmawati et al. (2013), Harun Sesen et.al (2012) , Nida Qomar (2012) concluded that organizational commitment is a mediating variable between job satisfaction and Organizational Citizenship Behavior.

\section{Limitations of Research}

This research was conducted in an economics college with a small number of samples, it is recommended for further research to examine the University with a larger number of samples and add research variables.

\section{Conclusion}

\section{Conclusion}

From the results of the research that has been conducted to determine the effect of job satisfaction on OCB mediated organizational commitment variables in Economics College of Indragiri Rengat, it can be concluded as follows:

1. Job satisfaction has a positive and significant effect on organizational commitment.

2. Organizational commitment has a positive and significant effect on Organizational Citizenship Behavior.

3. Job satisfaction has a positive and significant effect on Organizational Citizenship Behavior.

4. Organizational commitment mediates the effect of job satisfaction on Organizational Citizenship Behavior positively and significantly.

\section{Recommendation}

From the results of research that has been done to determine the effect of job satisfaction on OCB mediated organizational commitment variables in Economics College of Indragiri Rengat, then it is recommended as follows:

1. It is recommended that the organization improve employee job satisfaction.

2. It is recommended that everything in the organization is committed to developing the organization to be even better.

\section{References}

[1] Ali Shurbagi AM, Zahari IB. The Mediating Effect of Organizational Commitment on the Relationship between Job Satisfaction and Organizational Culture. International Journal of Business Administration. 2014 Nov 16;5(6). https://doi.org/10.5430/ijba.v5n6p24

[2] Barnes A dan Taksa L. Rethinking misbehavior and resistence in organizations. Emerald group publishing limited. UK; 2012. 
[3] Yavari I, Mohtat B, Zare H. Synthesis of 4,5-dialkyl 5-acetyl-3-oxo-3-(triphenylphosphoranylidene)tetrahydrofuran-4,5-dicarboxylates. Mendeleev $\quad$ Communications. $2006 \quad$ 01;16(2):102104. https://doi.org/10.1070/mc2006v016n02abeh002281

[4] Busro Muhammad. Teori-teori manajemen sumber daya manusia. Prenada Media Group. Jakarta; 2018.

[5] Budiharjo Andreas. Menuju Pencapaian kinerja Optimum. Prasetya Mulya Publishing. Jakarta; 2011.

[6] Chhabra B, Mohanty R, Gupta R. Mediating role of organisation commitment in the relationship between job satisfaction and organisational citizenship behaviour: a study of Indian IT professionals. International Journal of Indian Culture and Business Management. 2014;9(4):449. https://doi.org/10.1504/ijicbm.2014.065193

[7] Bismark AW, Thomas ML, Tarasenko M, Shiluk AL, Rackelmann SY, Young JW, Light GA. Relationship between effortful motivation and neurocognition in schizophrenia. Schizophrenia Research. 2018 03;193:69-76. https://doi.org/10.1016/j.schres.2017.06.042

[8] Fattah, Hussein. Kepuasan Kerja \& Kinerja Pegawai, Budaya Organisasi, Perilaku Pemimpin dan Efikasi Diri, Yogyakarta : Elmatera.. Fattah, Hussein; 2017.

[9] Gurbuz, S.. The Effects of Job Satisfaction and Justice Perception on Organizational Citizenship Behavior. Amme Idaresi Dergisi. 2008;41(4):49-77.

[10] Hariandja Efendi M.T.. Manajemen Sumber Daya Manusia. PT.Gramedia Widiasarana Indonesia. Jakarta; 2002.

[11] Kizilos MA, Cummings C, Cummings TG. How High-Involvement Work Processes Increase Organization Performance. The Journal of Applied Behavioral Science. 201303 17;49(4):413436. https://doi.org/10.1177/0021886313479998

[12] Kusumaputri E.S.. Komitmen pada perubahan organisasi. Yogyakarta: Deepublish; 2018.

[13] Dr. Rusliza Yahaya,Dr. Ibrahim Tamby Chek,Norsamsinar Samsudin, Dr. Jessnor Elmy Mat Jiza. ORGANIZATIONAL COMMITMENT AT A HIGHER EDUCATION 2(11), 309318. International Journal of Education and Research. 2014;2(11):309-18.

[14] Organ DW, Lingl A. Personality, Satisfaction, and Organizational Citizenship Behavior. The Journal of Social Psychology. 1995 06;135(3):339-350. https://doi.org/10.1080/00224545.1995.9713963

[15] Nida Qamar. Job Satisfaction and Organizational Commitment as Antecedents of Organizational Citizenship Behavior (OCB). Interdisciplinary Journal Of Contemporary Research In Business. 2017;4(7):103-22.

[16] Partono Prasetio A, Yuniarsih T, Ahman E. Job Satisfaction, Organizational Commitment, and Organizational Citizenship Behaviour in State-owned Banking. Universal Journal of Management. 2017 01;5(1):32-38. https://doi.org/10.13189/ujm.2017.050104

[17] Payne L.L dan Cooper C.L.. Emotion at Work: Theory, Research and Aplications. John Wiley and Sons Ltd. England; 2001.

[18] Rahman M. . Ilmu Administrasi. Penerbit CV. Sah Media. Makassar; 2017.

[19] Rayner J, Lawton A, Williams HM. Organizational Citizenship Behavior and the Public Service Ethos: Whither the Organization?. Journal of Business Ethics. 201108 18;106(2):117130. https://doi.org/10.1007/s10551-011-0991-X

[20] Robbins S.P dan Judge T.A. Perilaku Organisasi. PT. Salemba Empat. Jakarta; 2008.

[21] Schappe SP. The Influence of Job Satisfaction, Organizational Commitment, and Fairness Perceptions on Organizational Citizenship Behavior. The Journal of Psychology. 1998 05;132(3):277-290. https://doi.org/10.1080/00223989809599167 
[22] Sesen H, Basim NH. Impact of satisfaction and commitment on teachers' organizational citizenship. Educational Psychology. $2012 \quad$ 07;32(4):475491. https://doi.org/10.1080/01443410.2012.670900

[23] Siyoto.S.. Dasar metodologi penelitian. Literasi Media Publishing. Yogyakarta; 2015.

[24] Tharikh SM, Ying CY, Mohamed Saad Z, Sukumaran KA. Managing Job Attitudes: The Roles of Job Satisfaction and Organizational Commitment on Organizational Citizenship Behaviors. Procedia Economics and Finance. 2016;35:604-611. https://doi.org/10.1016/s2212-5671(16)00074-5

[25] Thoyib, A. . Peran Organizational Citizenship Behavior sebagai Mediator Pengaruh . 2011.

[26] Trifunac A, Thurnauer M, Norris J. Submicrosecond time-resolved EPR in laser photolysis. Chemical Physics Letters. 1978 08;57(3):471-473. https://doi.org/10.1016/00092614(78)85552-3

[27] Trisnantor.L.. Manajemen rumah sakit. Gajah Mada University Press. Yogyakarta; 2018.

[28] Turnipseed, D. L. . Handbook of OCB: A Review of Good Soldier Activity in Organizations. Handbook of Organizational CitizensHip Behavior; 2005.

[29] Umar Husein. Metode riset bisnis. PT. Gramedia Pustaka Utama. Jakarta; 2002.

[30] Wang Y. Examining organizational citizenship behavior of Japanese employees: a multidimensional analysis of the relationship to organizational commitment. The International Journal of Human Resource Management. 201104 05;26(4):425-444. https://doi.org/10.1080/09585192.2011.560882

[31] Wirawan . Kepemimpinan: Teori, psikologi, perilaku organisasi, Aplikasi dan Penelitian. PT. RajaGrafindo Persada. Jakarta; 2017.

[32] Zeinabadi H. Job satisfaction and organizational commitment as antecedents of Organizational Citizenship Behavior (OCB) of teachers. Procedia - Social and Behavioral Sciences. 2010;5:9981003. https://doi.org/10.1016/j.sbspro.2010.07.225

[33] Zeinabadi H. Job satisfaction and organizational commitment as antecedents of Organizational Citizenship Behavior (OCB) of teachers. Procedia - Social and Behavioral Sciences. 2010;5:9981003. https://doi.org/10.1016/j.sbspro.2010.07.225 